\title{
Butia capitata (Mart.) Becc. lamina anatomy as a tool for taxonomic distinction from B. odorata (Barb. Rodr.) Noblick comb. nov (Arecaceae)
}

\author{
BRUNO F. SANT'ANNA-SANTOS ${ }^{1}$, WELLINGTON G.O. CARVALHO JÚNIOR ${ }^{2}$ \\ and VANESSA B. AMARAL ${ }^{1}$ \\ ${ }^{1}$ Instituto de Ciências Agrárias, Universidade Federal de Minas Gerais, \\ Av. Universitária, 1000, 39404-547 Montes Claros, MG, Brasil \\ ${ }^{2}$ Departamento de Biologia Vegetal, Universidade Federal de Viçosa, \\ Av. PH Rolfs, s/n, 36570-000 Viçosa, MG, Brasil
}

Manuscript received on November 8, 2013; accepted for publication on January 30, 2014

\begin{abstract}
The distinction between Butia capitata and B. odorata is based only on a few morphological characteristics, therefore there is a need for additional studies for supporting the separation of the species. As lamina anatomy characteristics are relevant in circumscribing Arecaceae taxa, this work aimed to describe $B$. capitata lamina anatomy and compare it with $B$. odorata. Samples from the middle portion of the pinnae were collected and processed in accordance with standard plant anatomy techniques. The epidermis is uniseriate and composed of a thick cuticle and epicuticular waxes into like hooked filaments. The subsidiary cells that arch over the guard cells are located at the hypodermis. The mesophyll is isobilateral and compact. The vascular bundles are collateral with a sclerenchymatic sheath extension that reaches the hypodermis. The stegmata cells have spherical and druse-like silica bodies. The midrib faces the adaxial surface with a thick fibrous layer surrounding the vascular bundles adjacent to the chlorenchyma. The stratified expansion tissue is on the abaxial surface, within the boundary between the mesophyll and midrib. Raphides are only found in B. capitata. Small bundles of the midrib fully surround the fibrous cylinder only in B. odorata. These characteristics are diagnostic and useful for supporting the proposed separation.
\end{abstract}

Key words: plant anatomy, palms, raphides, taxonomy.

\section{INTRODUCTION}

The genus Butia (Becc.) Becc. belongs to the Arecaceae (Palmae) family, which comprises 18 species (Noblick 2010) and is monophyletic based on phylogenetic studies (Meerow et al. 2009). According to intrafamilial classification based on Arecaceae phylogeny (Dransfield et al. 2005), the genus is included in the Arecoideae subfamily, tribe Cocoseae

Correspondence to: Bruno Sant'Anna Santos

E-mail: bsantannaufmg@gmail.com and subtribe Attalainae. Among the species in the genus, 16 have been observed in Brazil (Noblick 2010).

According to Tomlinson (1961), the average number of species per genus in the Arecaceae family is only 13 , with only a few palm genera and numerous species and/or wide geographical distribution (Moore 1973). Thus, high levels of endemism are unsurprising because the distribution of Butia species is concentrated in the central highlands and southern Brazil (Noblick 2010). 
Even though it is a monophyletic group with few representatives, according to Glassman (1970), Butia forms a group with high morphological diversity, which has generated wide disagreements among different authors and resulted in significant changes to the genus taxonomy in recent years. Within this discussion, the species Butia capitata (Mart.) Becc. is distinctive and is a native palm first identified by Martius in 1826 with the basionym Cocos capitata. B. capitata has been observed in savanna and savanna woodland areas, typically in sandy soils, in Bahia, Goiás and Minas Gerais (Noblick 2010), which is popularly known as "coquinho-azedo". However, certain authors also attribute the name $B$. capitata to populations in south of Brazil (Henderson et al. 1995, Rosa et al. 1998), wherein the species is popularly known as "butiá".

However, Lorenzi et al. (2010) recently formally separated the Rio Grande do Sul populations from those in Bahia, Goiás and Minas Gerais and established that the binomial B. capitata should be exclusively adopted for the populations in Minas Gerais, Goiás and Bahia, but B. odorata should be used for the populations in Rio Grande do Sul. In the morphological description of $B$. capitata and B. odorata (Lorenzi et al. 2010), only one petiole character and the size of the fruit and endocarp shape, characterized as "slightly different", were emphasized to support the separation of the two species.

The correct delineation of different taxa and establishing relationships among groups of plant species are key issues at different hierarchical levels. For example, the taxonomy Butia is controversial, and contemporary taxonomic studies are inconsistent on the number of accepted species for this genus (Noblick 2010).

Consequently, researches have been steady for additional characteristics to support taxonomic and phylogenetic studies. Among such characteristics, plant anatomy is exceptional (Metcalfe and Chalk 1979) and has been used with additional information sources to clarify taxonomic problems and better interpret relationships among plant groups (Silva and Potiguara 2008, Araújo et al. 2010, Delgado et al. 2011). For palm trees, the leaf is the vegetative organ that provides the most diagnostic characteristics because the stem and root provide few important characteristics, according to Tomlinson (1961). In leaves, the lamina is where the greatest number of diagnostic anatomical characteristics are observed (Tomlinson et al. 2011), which justifies its study in taxonomy.

Thus, lamina anatomy data may be relevant because anatomical studies have been significant in discerning both ecological and evolutionary information, as well as circumscribing Arecaceae taxa (Uhl and Dransfield 1987, Tomlinson 1990, Horn et al. 2009, Tomlinson et al. 2011).

Therefore, the study herein was aimed at describing the lamina anatomy for $B$. capitata and comparing it with $B$. odorata to provide additional characteristics for supporting the proposed separation of the two species.

\section{MATERIALS AND METHODS}

Leaf samples for Butia capitata (Martius) Beccari and B. odorata (Barb. Rodr.) Noblick comb. nov were collected in the municipalities of Lontra/MG (Latitude S $15^{\circ} 56^{\prime} 24.2^{\prime \prime}$ and Longitude W $44^{\circ}$ 17' 50.7") and Tapes/RS (Latitude S 30 30' 42.4" and Longitude W $\left.51^{\circ} 20^{\prime} 58.2^{\prime \prime}\right)$, respectively. Samples collected in Lontra/MG and Tapes/RS were deposited, respectively, in the Herbarium of the Department of Botany, Federal University of Minas Gerais (BHCB-144649) and in the Alarich Schultz Herbarium of the Museum of Natural Sciences, Rio Grande do Sul Zoobotanical Foundation (HAS-47695).

The leaf samples were collected from the middle portion of the pinnae in five individuals from each of the three populations at each site. After collection, the samples were immediately fixed in $\mathrm{FAA}_{50}$ for 24 hours (Johansen 1940) and stored in $70 \%$ ethanol for a light microscopy study. 
For the light microscopy studies, the samples were stored in $70 \%$ ethanol, rehydrated and softened in $10 \%$ ethylenediamine for 12 hours (Kraus and Arduin 1997). To prepare the semi-permanent slides, after softening, portions of the leaf fragments were transversely and longitudinally sectioned on a microtome table (model LPC, Rolemberg e Bhering Comércio e Importação LTDA., Belo Horizonte, Brazil) with a disposable razor blade. The histological sections were directly mounted in glycerin water or pre-stained with Safranin and Astra blue. Polarized light and autofluorescence were used for the unstained sections to examine the samples under UV light (330-385 nm) and yellow light $(450-490 \mathrm{~nm})$ as well as to detect lignins (Ascensão et al. 1999).

To prepare the permanent slides, the samples were embedded in methacrylate (Historesin, Leica Instruments, Hidelberg, Germany) and $5 \mu$ m-thick cross sections were prepared in an automatic rotary microtome (model RM2155, Leica Microsystems Inc., Deerfield, USA) with glass knives and stained with $\mathrm{pH} 4.0$ toluidine-blue (O'Brien and McCully 1981). The slides were mounted in synthetic resin (Permount $^{\circledR}$, Fischer).

To describe the epidermis from the frontal perspective and collect the mesophyll macerate, $1 \mathrm{~cm}^{2}$ pinnae fragments were dissociated under immersion in $10 \%$ nitric acid and $10 \%(\mathrm{v} / \mathrm{v})$ chromic acid (Jensen 1962). The epidermal fragments were stained with safranin in an ethanol solution (Johansen 1940, modified), and the semipermanent slides were mounted on glycerinated gelatin. The mesophyll macerate was stained with safranin, and the permanent slides were mounted in synthetic resin (Permount ${ }^{\circledR}$, Fischer).

Photographs were generated using a digital camera coupled with a light microscope equipped with a U-Photo system (model Olympus AX70TRF, Olympus Optical, Tokyo, Japan).

For the scanning electron microscopy analysis, the samples were fixed in Karnovsky's solution
(Karnovsky 1965), dehydrated in ethylic series and dried until the critical point (model CPD 020, BalTec, Balzers, Liechtenstein). The fragments were covered with gold using the cathodic spray process in a Sputter Coater (model FDU010, Bal-Tec, Balzers, Liechtenstein). The analyses were made using DSM900, 940A, Zeiss, Cambridge, England.

\section{RESULTS AND DISCUSSION}

On both surfaces, the stomata are in continuous longitudinal rows that are restricted to the intercostal region at high levels on both pinnae surfaces (Fig. 1A-B), which is consistent with the genus description (Tomlinson 1961). However, they are organized in continuous and distinct longitudinal rows. According to Tomlinson (1961), this type of organization is rare but has been observed in palms with high stomata densities.

The stomata are tetracytic with terminal (polar), short and hexagonal subsidiary cells as well as lateral (parallel to the ostiole), elongated cells with similar lengths to the guard cells (Fig. 1C). The lamina is covered by epicuticular wax in the form of hooked filaments (Fig. 1D). In a cross section, the lateral subsidiary cells have an arciform shape and are deep at the guard cell level on the adaxial (Fig. 1E) and abaxial (Fig. 1F) surfaces. However, the distal portion of the lateral subsidiary cells reaches the same level as the ordinary cells (Fig. 1E-G). The guard cells are at the hypodermis level (full depth) with a thin wall as well as a prominent external and internal stomatal ledge and are coated with epicuticular wax (Fig. 1D-F). The frontal perspective presents a hexagonal shape with a non-sinuous contour for the ordinary epidermal cell anticlinal walls. In a cross section, the ordinary cells have a thick cuticle on both pinnae surfaces (Fig. 1E-G).

The mesophyll is isobilateral and compact (Fig. 1H), which are characteristics restricted to a few genera in the family Arecaceae (Tomlinson et al. 2011) and previously described by Horn et 
al. (2009). Notably, in this family, only Butia and Phoenix have pinnate leaves with isobilateral mesophyll (Tomlinson et al. 2011), which demonstrates the importance of this diagnostic characteristic for the genus. The organization of the tissues that face the adaxial and abaxial surfaces (except for vascular tissues) are virtually identical (Fig. 1H), which has motivated certain authors to state that the two leaf surfaces are mirror images (Horn et al. 2009). For the frontal epidermis perspective, the surfaces are highly similar. The stomata and palisade parenchyma are positioned such that both pinnae surfaces maximize the potential for carbon dioxide distribution inside the leaf(Vogelmann and Martin 1993). In environments with high irradiance, isobilateral leaves operate at a higher photosynthetic rate per unit of biomass than dorsiventral leaves (Fahn and Cutler 1992).

The palisade parenchyma on both surfaces are formed by three to five layers of elongated and slightly overlapping cells (Fig. 1H). Between the two palisade parenchyma surfaces, the parenchyma cells located in the innermost portion of the leaf are bulky, spherical and elongated, and they form the central chlorenchyma (Fig. 1H). Adjacent to the epidermis in the intercostal region on both pinnae surfaces is a hypodermis layer, which is often interrupted by stomata cells that are bulkier than ordinary epidermis cells (Fig. 1E-F). These stomata cells have thicker walls with compounds that produce blue autofluorescence under yellow light (Fig. 1I and K) and are yellow under UV light (Fig. 1J and L), which is the same coloration for lignified walls. However, for the hypodermis, Tomlinson et al. (2011) noted that typically such cells have thin and non-lignified walls. In the costal region, the hypodermis can form two or more layers composed of more longitudinally elongated cells on the adaxial surface and more quadrangular cells on the abaxial surface (Fig. 1I). However, the isobilateral palm leaf hypodermis is identical on both pinna surfaces (Tomlinson 1961).
The venation is parallel with longitudinal ribs transversely connected by commissures (Fig. 2A) that are approximately equidistant from each pinnae surface (Fig. 2A and B), which is consistent with previous descriptions for the genus (Tomlinson 1961). The secondary and tertiary vascular bundles in Butia are classified into the following three main types using Tomlinson's classification scheme (1961): (i) bundles with larger diameters, four phloem poles and a sclerenchymatic sheath extension associated with the innermost hypodermis layer on both epidermal surfaces (Fig. 2C); (ii) similar to (i) but with undivided phloem (Fig. 2D); and (iii) the most frequent type with a smaller diameter and sclerenchymatic sheath extension that contacts the hypodermis on only one epidermal surface, which is typically located above or below a similar bundle or, more rarely, above or below a fiber bundle or small vascular tissue surrounded only by parenchyma (Fig. 2B and E). The bundles with a smaller diameter are arranged in two series of fiber caps associated with and adjacent to the respective epidermal surface (Fig. $2 \mathrm{E}$ and $\mathrm{F}$ ). The secondary vascular bundles (types $\mathrm{i}$ and ii) and tertiary (iii) are collateral, fully or partly surrounded by sclerenchymatic sheath (Fig. 2C and D), emit blue autofluorescence under yellow light (Fig. 1I) and are yellow under UV light (Fig. $1 \mathrm{~J})$. The tertiary bundles have no distinguishable protoxylem and metaxylem (Fig. 2E), which are observed for secondary bundles (Fig. 2C and D).

In the pinnae margin, the tertiary vascular bundle facing the adaxial surface (Fig. $2 \mathrm{~F}$ and $\mathrm{G}$ ) has a smaller sclerenchymatic sheath reinforcement, compared with the tertiary bundle facing the abaxial surface (Fig. 2F and $\mathrm{H}$ ). According to Tomlinson (1961), the pinnae margins are not reinforced in the Butia species described by the author. The margin has a quadrangular shape and features numerous crystal idioblasts (Fig. 2I-M) that have not been described for vegetative organs in this genus. The raphides were also observed in 

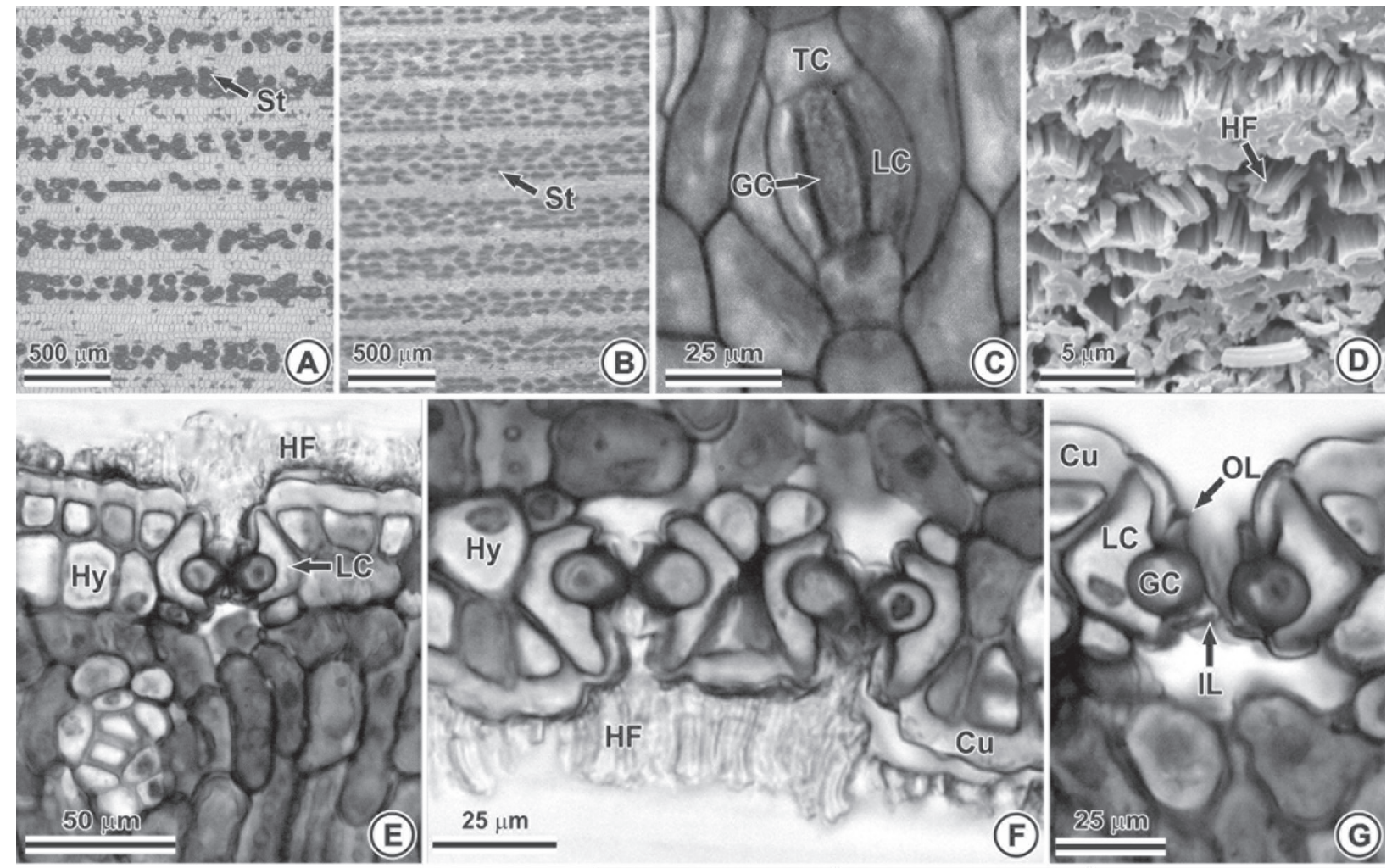

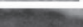

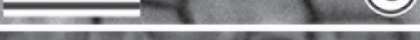
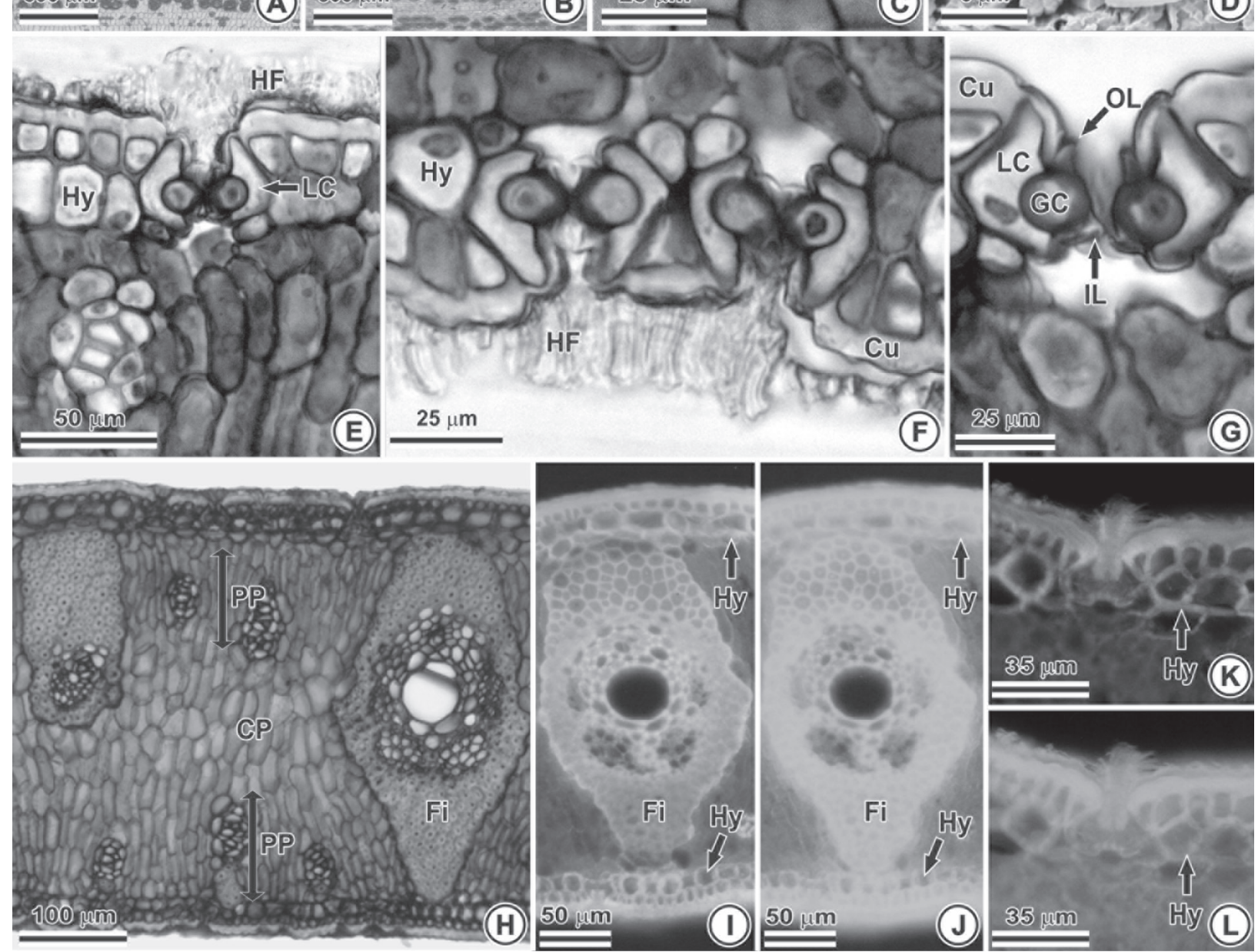

Figure 1 - Epidermis and mesophyll of Butia capitata. (A-D) Front view under light (A-C) and scanning electron microscopy (D). (E-L) Cross sections under light microscopy. (A-B) Stomata rows on the adaxial (A) and abaxial (B) epidermis. (C) Lateral cells. (D) Hooked filaments. (E) Guard-cells. (F) Cuticle. (G) Stomatal ledge. (H) Palisade parenchyma. (I-L) Hypodermis under yellow (I,K) and UV (J,L) light. St - Stomata, TC - Terminal cell, LC - Lateral cell, GC - Guard-cell, OL - Outer ledge, IL - Inner ledge, $\mathrm{Cu}$-Cuticle, HF - Hooked filaments, Hy - Hypodermis, PP - Palisade parenchyma, CP - Central parenchyma, Fi - Fibers.

the intermediate region. The idioblasts are arranged in discontinuous, longitudinal rows with raphids and dense mucilaginous matter (Fig. 2J and L), as described by Tomlinson (1961).
Stegmata cells with druse-like and spherically shaped silica bodies are associated with sclerenchymatic sheath fibers in the vascular bundles (Fig. 3). Druse-like silica bodies are 

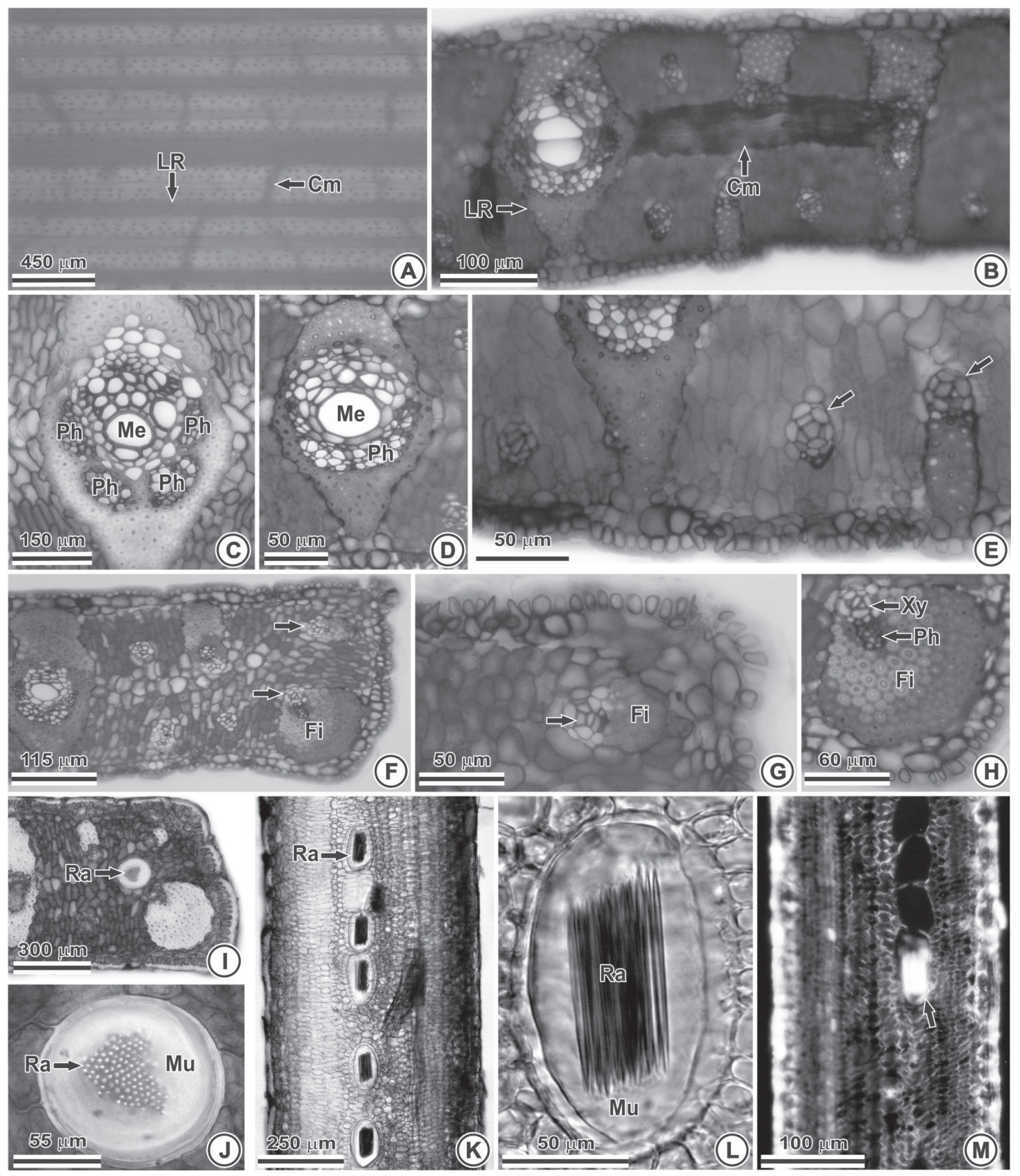

Figure 2 - Vascular bundles and idioblasts of Butia capitata under light microscopy. (A) Front view. (B-J) Cross sections. (K-M) Longitudinal sections. (A) Longitudinal ribs. (B) Commissures. (C) Phloem poles. (D) Undivided phloem. (E-F) Arrows shows tertiary bundles. (G-H) Tertiary bundle facing the adaxial (G) and abaxial (H) surfaces. (I). Raphides. (J). Mucilage. (K). Raphides row. (L). Mucilage. (M). Raphids (polarized light). LR - Longitudinal ribs, $\mathrm{Cm}$ - Comissures, Ph - Phloem, Me - Metaxylem, Fi - Fibers, Xy - Xylem, Ra - Raphides, Mu - Mucilage.

commonly observed in leaves from different groups of monocots (Prychid et al. 2004); however, they have not been noted in the anatomical descriptions for Butia (Tomlinson 1961, Tomlinson et al. 2011).
The stegmata cells are associated with nonvascular fibers in both the mesophyll (Fig. 3A-B and E) and hypodermis (Fig. 3D and F-G) and are more frequent, larger and druse-like when facing the 
abaxial surface (Fig. 3D-I). In the hypodermis, the stegmata cells are in discontinuous and longitudinal rows, restricted to the costal region (Fig. $3 \mathrm{~F}$ and G) and give a false impression that they are in the epidermis from the frontal perspective. However, certain authors have described stegmata in the epidermis (Passos and Mendonça 2006) in contrast with that postulated by Tomlinson (1961) for palm trees in general and with the work herein. Stegmata cells are in all palm tree species and are generally associated with vascular and nonvascular fibers (Tomlinson 1961). Furthermore, the silica body shape is a useful characteristic for the family Arecaceae taxonomy (Uhl and Dransfield 1987). An additional characteristic with considerable taxonomic potential is the position of the silica bodies, which are also only slightly influenced by environmental factors (Prychid et al. 2004). Leite and Scatena (2001) noted that the silica body lined arrangement may be an important taxonomic characteristic for the genus Syagrus, which includes $B$. capitata according to Glassman (1972). Furthermore, the silica is related to the plant's defense against desiccation and herbivory (Leite and Scatena 2001) because the silica bodies in the superficial tissues prevent collapse of adjacent tissues under water stress and mechanically protect against insect attacks (Metcalfe 1985).

The midrib is more prominent on the adaxial surface (Fig. 3J), which was previously observed for Butia (Tomlinson 1961, Glassman 1972) and is characteristic of palm trees with reduplicated leaves (Tomlinson 1961). The midrib vascular system is formed by two main vascular bundles; the largest bundle faces the abaxial midrib with four phloem caps and is well-delimited by a fibrous cylinder (Fig. 3J and $\mathrm{K}$ ). The main vascular bundles are fully surrounded by the fibrous cylinder, which was demonstrated through blue autofluorescence under yellow light (Fig. 3L) as well as yellow fluorescence under UV light (Fig. 3M), and composes a large proportion of the midrib. Outside of the fibrous cylinder, 18 to 21 small bundles are immersed in the chlorenchyma and arranged around almost all of the midrib; distribution is interrupted at the abaxial surface, where the fibrous layer protrudes and reaches the hypodermis (Fig. 3L-M). At the border with the intermediate pinna region and adjacent to the abaxial surface, hypodermic palisade cells that are longitudinally more elongated with thickened walls are arranged obliquely to the diagonal (Fig. $3 \mathrm{~N}-\mathrm{P}$ ), were identified as expansion tissue by Tomlinson (1961). The expansion tissue is formed by three to four layers of bulky hypodermic cells with walls that autofluoresce blue under yellow light (Fig. 3O) and yellow under UV light (Fig. $3 \mathrm{P}$ ), which is the same color as lignified tissues, and is arranged in two bundles of cells, one on each side of the midrib. According to Glassman (1972), expansion tissue composes half of the area for the midrib vascular bundle. However, herein, this proportion is visually smaller. On the adaxial surface, the epidermal cells are similar to those in the lamina. However, on the abaxial surface, the epidermal cells adjacent to the expansion tissue bundle are papillary and highly cutinized (Fig. $3 \mathrm{~N}$ ), which is common in the epidermis adjacent to the expansion tissue (Tomlinson 1961). The midrib adaxial surface hypodermis is formed by two to three layers of cells, which differs from the intermediate region of the leaf and is consistent with Glassman's description (1972).

Despite the similarity described above for the two species' anatomy, certain differences have been observed. In the midrib region, the outline of the adaxial surface is more rounded in $B$. capitata (Fig. 4A) than in B. odorata, which has a more quadrangular outline (Fig. 4B). The small midrib bundles completely encircle the fibrous cylinder only in B. odorata (Fig. 4B, D and F) because its distribution is interrupted by the fibrous cylinder extension in B. capitata, which connects to the epidermis on the abaxial surface (Fig. 4A, C and 

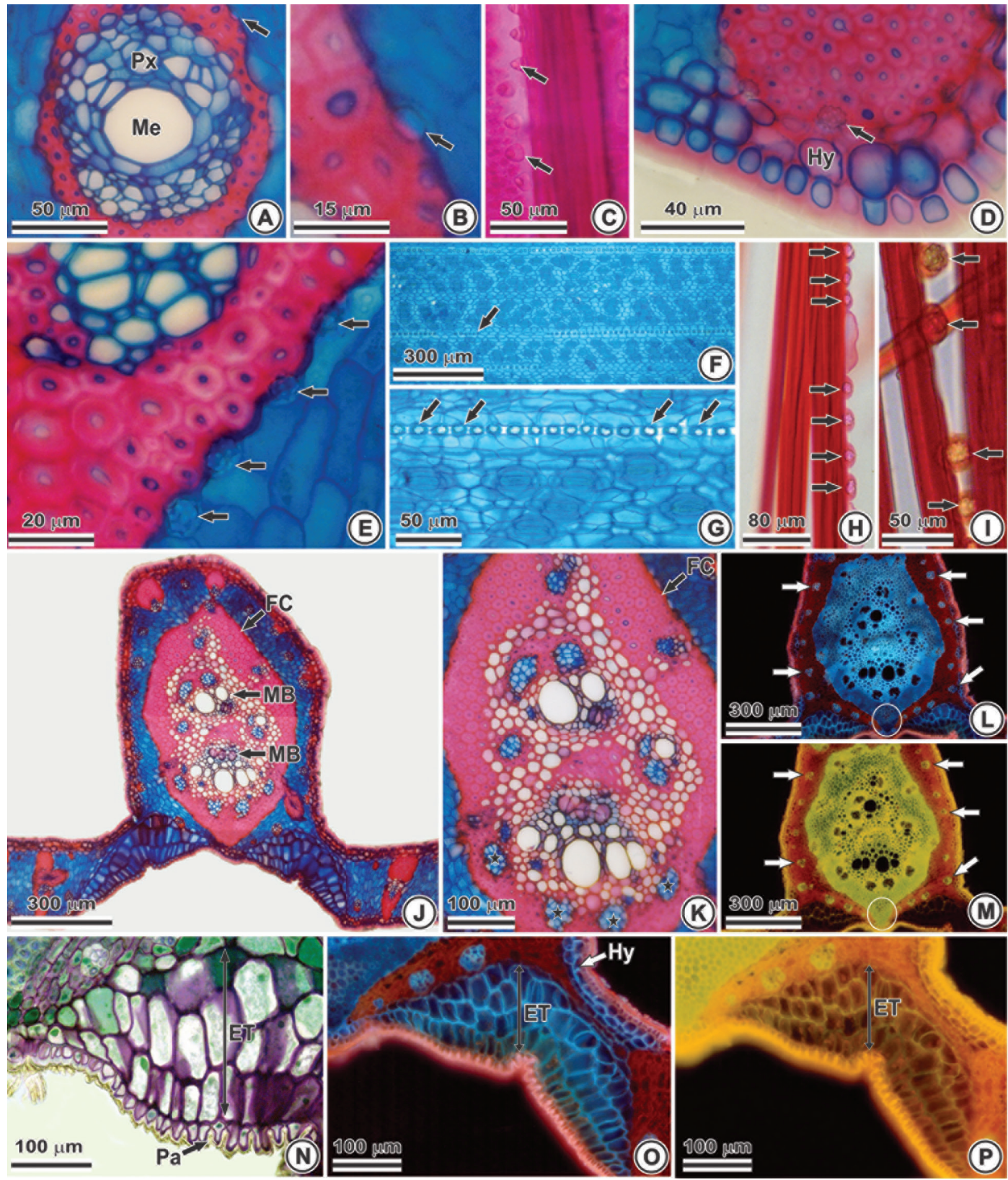

Figure 3 - Stegmata and midrib anatomy of Butia capitata under light microscopy. (A-B, D-E, J-P) Cross sections. (F-G) Front view. (C, H-I) Macerate. (A-C) Arrows shows spherical silica bodies. (D-I) Druse-like silica bodies near hypodermis (D), mesophyll (E). (F-G) Discontinuous rows (adaxial). (H-I) Fiber-associated stegmata. (J) Main bundles. (K) Fibrous cylinder. (L-M) Fibrous cylinder (circle) adjacent to the hypodermis and small bundles (arrows) under yellow (L) and UV (M) light. (N) Papillae. (O-P) Expansion tissue under yellow (O) and UV (P) light. Me - Metaxylem, Px - Protoxylem, Hy - Hypodermis, FC - Fibrous cylinder, MB - Main bundle, ET - Expansion tissue, Pa - Papillae. 
E). In the foliar margin, idioblasts with raphides are in B. capitata (Fig. 4G) but not in B. odorata (Fig. 4H). According to Tomlinson (1961), the raphides most likely occur in all palm tree organs.
According to Tomlinson (1961), the raphides may be infrequent and seem absent. However, a large amount of leaf material from $B$. odorata was analyzed without observation of such crystals.
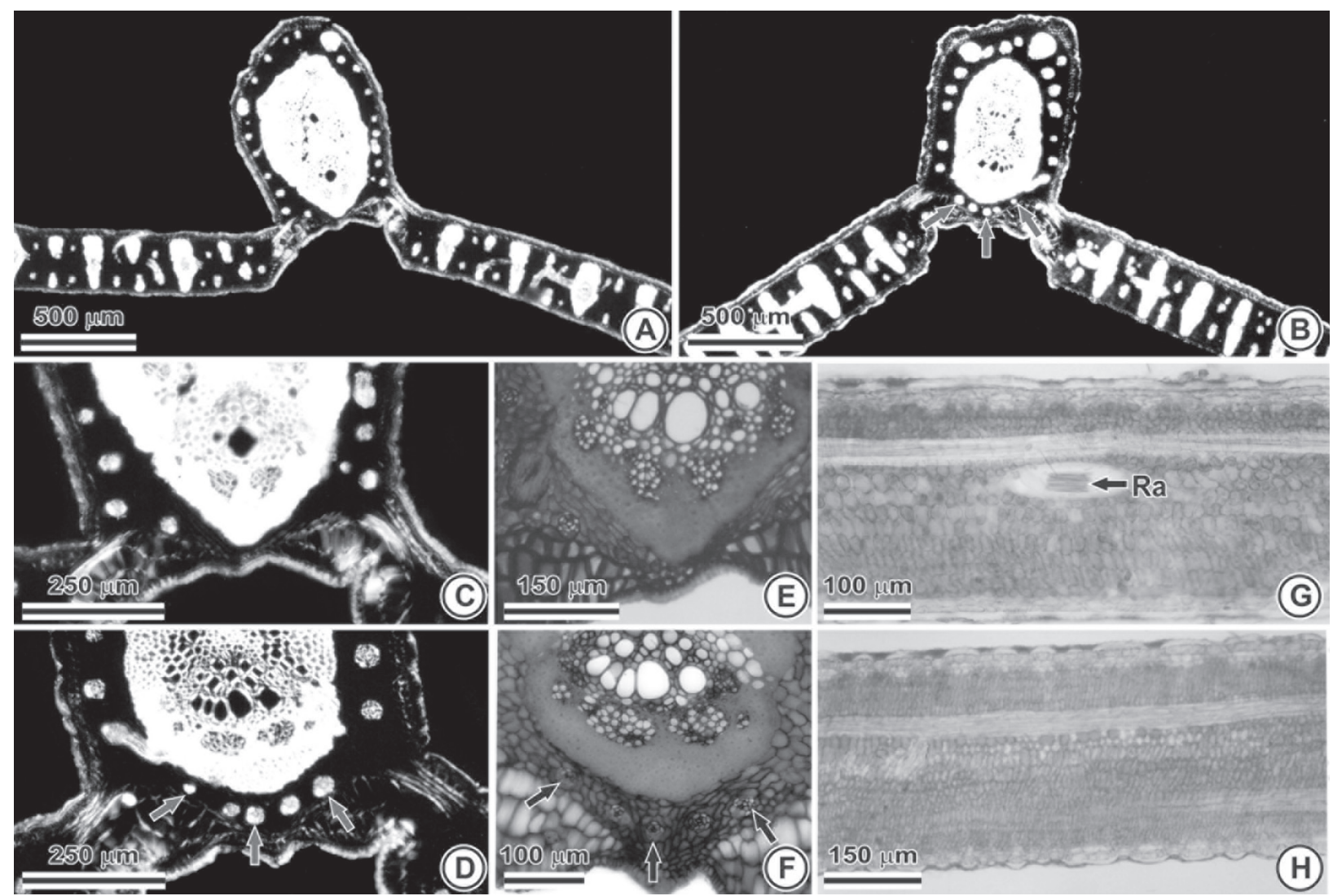

(G)

Figure 4 - Leaf anatomy distinctive characteristics of Butia capitata (A, C, E, G) and B. odorata (B, D, F, H) under light microscope. (A-F) Cross sections. (G-H) Longitudinal sections. (A-D) Distribution of small bundles (arrow) under polarized light. (E-F) Distribution of small bundles under visible light. (G-H) With (G) and without (H) raphids. Ra - Raphids.

The characteristic described for the epidermis (except the arrangement of the stomata non-papillose cells near the stomata), the isobilateral mesophyll, the hypodermis and vascular bundle types i, ii and iii are unifying at the genus level compared with the Butia anatomy described by Tomlinson (1961).

Herein, the raphids, epicuticular wax in the form of hooked filaments, druse-like silica bodies and difference in hypodermis cell shape between the adaxial as well as abaxial surfaces and the hypodermis (including the expansion tissue) with thick walls containing compounds that react to autofluorescence similar to lignified tissues, have not been described in the literature for Butia. Likely such characteristics were not previously identified because they are difficult to discern in studies where a large number of species are analyzed and authors commonly opt for rapid and simple methodologies (Tomlinson 1961, Glassman 1972, Horn et al. 2009), which supports the importance of further analysis in identifying diagnostic characteristics through different methods.

Idioblasts containing raphides and small bundle distribution type in the midrib are characteristic 
of the foliar anatomy that differentiates Butia capitata from B. odorata. Despite collection sites' environmental differences, those distinctive characteristics are not environmentally influenced (Sant'Anna-Santos et al. unpublished data). In addition to supporting the separation proposed by Lorenzi et al. (2010), these data may aid in recognizing such species and demonstrate that foliar anatomy can provide important data for taxonomy of the genus Butia.

\section{ACKNOWLEDGMENTS}

The authors would like to thank Claudimar Sidnei Fior and Érica Duarte Silva from the Universidade Federal do Rio Grande do Sul (UFRGS) for their assistance with sample collection; the Laboratório de Anatomia Vegetal from the Universidade Federal de Viçosa (UFV) for assisting with light microscopy; the Núcleo de Apoio à Pesquisa em Microscopia Eletrônica Aplicada à Pesquisa Agropecuária from the Universidade de São Paulo (USP) for assisting with electron microscopy; the Fundação de Amparo à Pesquisa do Estado de Minas Gerais (FAPEMIG - CRA APQ 01043/11) and the Pró-Reitoria de Pesquisa from the Universidade Federal de Minas Gerais (UFMG) for the financial support.

\section{RESUMO}

A distinção de Butia capitata e de $B$. odorata é baseada em poucos caracteres morfológicos, o que motiva a busca por mais dados que corroborem a separação. Como dados da anatomia foliar são relevantes na circunscrição de taxa em Arecaceae, objetivou-se descrever a anatomia foliar de $B$. capitata e comparar com a de $B$. odorata. Amostras da porção mediana das pinas foram coletadas e processadas de acordo com técnicas usuais em Anatomia Vegetal. A epiderme é unisseriada e possui cutícula espessa e ceras epicuticulares em formato de filamentos em anzol. As células subsidiárias arqueiamse sobre as células-guarda localizadas no nível da hipoderme. O mesofilo é isobilateral e compacto. Os feixes vasculares são colaterais com extensão de bainha esclerenquimática alcançando a hipoderme. Stegmatas possuem corpos silicosos esféricos e drusóides. A nervura mediana é adaxialmente projetada, apresentando espessa camada fibrosa que circunda os feixes vasculares, adjacente ao parênquima clorofiliano. Tecido de expansão estratificado ocorre na face abaxial, nos limites do mesofilo com a nervura mediana. Ráfides ocorrem apenas em B. capitata. Os feixes diminutos da nervura mediana circundam totalmente o anel fibroso somente em B. odorata. Além de diagnósticos, esses caracteres são úteis para corroborar a separação atualmente proposta.

Palavras-chave: anatomia vegetal, palmeiras, ráfides, taxonomia.

\section{REFERENCES}

Araújo JS, AZEvedo AA, Silva LC AND MeIra RMSA. 2010. Leaf anatomy as na additional taxonomy tool for 16 species of Malpighiaceae found in the Cerrado área (Brazil). Plant Syst Evol 286: 117-131.

Ascensão L, Mota L AND CASTRO MM. 1999. Glandular trichomes on the leaves and flowers of Plectranthus ornatus: Morphology, distribution and histochemistry. Annals Bot 84: 437-447.

Delgado MN, AzeVedo AA, Silva LC, Valente GE AND KASUYA MCM. 2011. Comparative anatomy of Calolisianthus species (Gentianaceae - Helieae) from Brazil: Taxonomic aspects. Edinburgh J Bot 68: 139-155.

DRANSFIELD J, UHL NW, ASMUSSEN CB, BAKER WJ, HARLEY MM AND LEWIS CE. 2005. A new phylogenetic classification of the palm family, Arecaceae. Kew Bull 60: 559-569.

FAHN A AND CUTLER DF. 1992. Xerophytes. Gebruder Bomtraeger, Berlim, $180 \mathrm{p}$.

GLASSMAN SF. 1970. A conspectus of the palm genus Butia Becc. Fieldiana Bot 32: 127-171.

GLASSMAN SF. 1972. Systematic studies in the leaf anatomy of palm genus Syagrus. Am J Bot 59: 775-788.

Henderson A, Galeano G AND Bernal R. 1995. Field guide to the palms of the Americas. Princeton University Press, New Jersey, $363 \mathrm{p}$.

HORN JW, Fisher JB, TOMLINSON PB, LEWIS CE AND LAUBENGAYER K. 2009. Evolution of lamina anatomy in the palm family (Arecaceae). Am J Bot 96: 1462-1489.

Jensen WA. 1962. Botanical Histochemistry: Principles and Practice. W.H. Freeman, San Francisco, 408 p.

JoHANSEN DA. 1940. Plant microtechnique. McGraw Boks, New York, $523 \mathrm{p}$.

KARNOVSKY MJ. 1965. A formaldehyde-glutaraldehyde fixative of high osmolarity for use in electron microscopy. J Cell Biol 27: 137-138. 
KRAUS JE AND ARDUIN M. 1997. Manual básico de métodos em morfologia vegetal. EDUR, Rio de Janeiro, 198 p.

LEITE KR AND SCATENA VL. 2001. Anatomia do segmento foliar de espécies de Syagrus Mart. (Arecaceae) da Chapada Diamantina, Bahia, Brasil. Sitientibus 1: 3-14.

LORENZI H, Noblick LR, KAHN F AND FerReIRA E. 2010. Flora brasileira. Lorenzi: Arecaceae (palmeiras). Instituto Plantarum, Nova Odessa, 384 p.

Meerow AW, Noblick L, Borrone JW, Couvreur TLP, Auro-Herrera M, HaHN WJ, KUHN DN, NAKAMURA K, OlEAS NH AND SCHNELL RJ. 2009. Phylogenetic analysis of seven WRKY genes across the Palmae subtribe Attaleinae (Arecaceae) identifies Syagrus as sister group of the coconut. PLoS ONE 4: e7353.

MetCALfe CR. 1985. Silica, In: Metcalfe CR and Chalk L (Eds), Anatomy of Dicotyledons. Claredon Press, Oxford. 2: 91-94.

Metcalfe CR AND CHALK L. 1979. Anatomy of the dicotyledons. Systematic anatomy of leaf and stem, with a brief history of the subject. $2^{\text {nd }}$ ed., Clarendon Press, Oxford, $304 \mathrm{p}$.

MOORE JR HE. 1973. Palms in the tropical forest ecosystems of Africa and South America, In: Meggers BJ, Ayensu ES and Duckworth DD (Eds), Tropical Forest Eco-systems of Africa and South America: a Comparative Review. Smithsonian Inst. Press, Washington DC, p. 63-88.

NoBlick LR. 2010. Butia, In: Lorenzi H, Noblick LR, Kahn F and Ferreira E (Eds), 2010. Flora brasileira. Lorenzi: Arecaceae (palmeiras). Instituto Plantarum, Nova Odessa, p.159-184.
O'BRIEN PP AND MCCULlY ME. 1981. The study of plants structure principles and select methods. Termarcarphi Pty. Ltda, Melbourne-Australia, $45 \mathrm{p}$.

PAssos MAB AND MendonçA MS. 2006. Epiderme dos segmentos foliares de Mauritia flexuosa L. F. (Arecaceae) em três fases de desenvolvimento. Acta Amaz 36: 431-436.

PRYCHID CJ, RUdAll PJ AND GREGORY M. 2004. Systematics and Biology of Silica Bodies in Monocotyledons. Bot Rev 69: $377-440$.

Rosa L, Castellani TT AND Reis A. 1998. Biologia reprodutiva de Butia capitata (Martius) Beccari var. odorata (Palmae) na restinga do município de Laguna, SC. Rev Bras Bot 21: 281-287.

SiLVA RJF AND PotiguaRA RCV. 2008. Aplicações taxonômicas da anatomia foliar de espécies amazônicas de Oenocarpus Mart. (Arecaceae). Acta Bot Bras 22: 999-1014.

TOMLINSON PB. 1961. Anatomy of the monocotyledons: II Palmae. Clarendon Press, Oxford, 453 p.

TOMLinson PB. 1990. The strutuctural biology of palms. Clarendon Press, Oxford, $465 \mathrm{p}$.

TOMLINSON PB, HoRn JW AND FisHER JB. 2011. The anatomy of palms. Clarendon Press, Oxford, 276 p.

Uhl NW And Dransfield J. 1987. Genera Palmarum - a classification of palms based on the work of Harold E. Moore Jr. Lawrence. Hortorium and the International Palm Society, Lawrence, Kansas, 610 p.

Vogelmann TC AND MARTIN G. 1993. The functional significance of palisade tissue: penetration of directional versus diffuse light. Plant Cell Environ 16: 65-72. 
